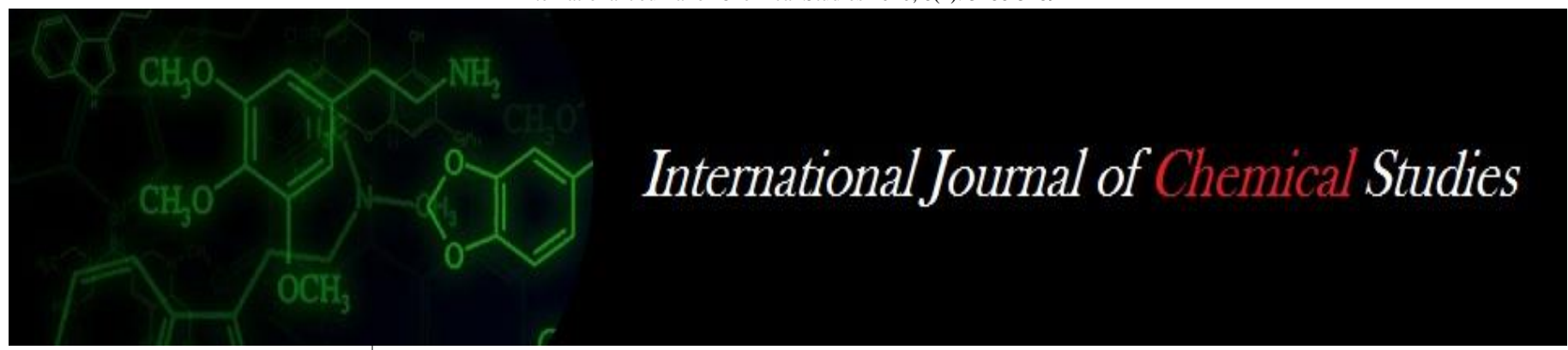

P-ISSN: 2349-8528

E-ISSN: 2321-4902

www.chemijournal.com

IJCS 2020; 8(4): 3188-3189

(C) 2020 IJCS

Received: 20-05-2020

Accepted: 21-06-2020

\section{A Poorani}

Assistant Professor, Veterinary college and Research Institute Namakkal, Tamil Nadu, India

B Suresh Subramonian

Professor, Madras Veterinary

College, Chennai, India

\section{A Elango}

Professor, Veterinary college and Research Institute Namakkal, Tamil Nadu, India

\section{G Kumaresan}

Professor, Veterinary college and Research Institute Namakkal,

Tamil Nadu, India
Corresponding Author:

\section{A Poorani}

Assistant Professor, Veterinary

college and Research Institute

Namakkal, Tamil Nadu, India

\section{Evaluation of yield of chakka and total solids in soy enriched probiotic shrikhand}

\author{
A Poorani, B Suresh Subramonian, A Elango and G Kumaresan
}

DOI: $\underline{\text { https://doi.org/10.22271/chemi.2020.v8.i4am.10141 }}$

\begin{abstract}
The effects of neutraze enzyme in soy enriched probiotic shrikhand was studied. The yield of chakka and total solids in soy enriched enzymatically modified probiotic shrikhand was determined by treating with Neutrase. Synbiotic Milk was prepared by substitution of enzymatically modified soymilk to bifidogenic milk at 10 per cent, 15 per cent and 20 per cent levels. It was found that the yield of chakka from SSyM 15 is $24.63 \pm 0.99$ and there is significant increase in yield of chakka $(P<0.01)$ with addition of neutrase in soy enriched enzymatically modified probiotic shrikhand. It was found that there was significant decrease in total solids recovery with increasing substitution of Neutrase at SSyM10, SSyM15 and SSSyM20.
\end{abstract}

Keywords: Soy enriched probiotic shrikhand-Neutrase-Synbiotic milk

\section{Introduction}

Srikhand is sweetened and sour taste popular Indian dessert prepared by the fermentation of milk. To make it more acceptable dietetic food, partially skimmed milk, soy milk, Enzyme (Neutrase) and probiotic micro organism Bifidobacterium longum were used for the preparation of soy enriched enzymatically modified probiotic shrikhand.(Kulkarni et al, 2006) [3].

For small-scale production of shrikhand the traditional method is followed widely. In this traditional method milk is heat treated and after bringing it room temperature,it was fermented using a culture to make curd, and then filtered using a muslin cloth to remove whey. The thickened mass obtained known as chakka is pressed over a strainer to get a smooth product which when mixed with sugar gives shrikhand.

\section{Material and methods}

Soy flour was procured from market and was used to prepare soy milk. It was treated with proteolytic enzyme, Neutrase for the preparation of Enzymatically Modified Soy Milk and subsequent addition to synbiotic milk (SyM) at 10, 15, 20 per cent levels. Bifidobacterium longum culture was activated by propagation in reconstituted sterile skim milk. Enzymatically modified synbiotic soy milk was treated with $1.5 \%$ starter culture and incubated at $37^{\circ} \mathrm{C}$ for about 10 hours to reach acidity of $1 \%$. (Boghra et al, 2000) ${ }^{[1] .}$

The whey was drained and chakka that was collected was kneaded with sugar and cardamom to make delicious soy enriched enzymatically modified probiotic shrikhand.

Yield and total solids recovery

The yield of chakka was calculated from the ratio of the weight of curd used and weight of chakka obtained.

$$
\text { Per cent of yield }=\frac{\text { Weight of chakka }}{\text { Weight of curd }}
$$

The total solids content of chakka was estimated as per FSSAI standards ${ }^{[2]}$.

\section{Total solids}

The total solids content of chakka was estimated as per FSSAI Manual method of analysis of foods: Milk and milk products-2015. 


\section{Results}

The yield of chakka and total solids in soy enriched enzymatically modified probiotic shrikhand are given hereunder.

Table 1: Yield of chakka in soy enriched enzymatically modified probiotic shrikhand

\begin{tabular}{|c|c|}
\hline Curd samples & Percent Yield of chakka \\
\hline Control & $22.32^{\mathrm{a}} \pm 0.08$ \\
\hline $\mathrm{SSyM}_{10}$ & $23.01^{\mathrm{b}} \pm 0.28$ \\
\hline $\mathrm{SSyM}_{15}$ & $24.63^{\mathrm{c}} \pm 0.99$ \\
\hline $\mathrm{SSyM}_{20}$ & $25.11^{\mathrm{c}} \pm 0.70$ \\
\hline $\mathrm{F}$ & $64.34^{* *}$ \\
\hline
\end{tabular}

Table 2: Yield of total solids in soy enriched enzymatically modified probiotic shrikhand

\begin{tabular}{|c|c|}
\hline Curd samples & Percent Yield of Total solids \\
\hline Control & $61.57^{\mathrm{a}} \pm 0.16$ \\
\hline SSyM $_{10}$ & $59.56^{\mathrm{b}} \pm 0.19$ \\
\hline SSyM $_{15}$ & $57.88^{\mathrm{c}} \pm 0.42$ \\
\hline SSyM $_{20}$ & $54.38^{\mathrm{d}} \pm 0.68$ \\
\hline $\mathrm{F}$ & $42.88^{* *}$ \\
\hline
\end{tabular}

\#Percentages (Mean \pm SE). Average of six trials. Mean values bearing different superscripts in a column differ significantly $* *(P<0.01)$

Control Shrikhand from Synbiotic milk, 1.5\% starter culture

SSyM $_{10}$ Shrikhand prepared from Synbiotic Milk by substitution of enzymatically modified soymilk to bifidogenic milk at 10 per cent level, $1.5 \%$ starter culture

SSyM $_{15}$ Shrikhand prepared from Synbiotic Milk by substitution of enzymatically modified soymilk to bifidogenic milk at 15 per cent level, $1.5 \%$ starter culture

SSyM $_{20}$ Shrikhand prepared from Synbiotic Milk by substitution of enzymatically modified soymilk to bifidogenic milk at 20 per cent level, $1.5 \%$ starter culture

Table 1 and Table 2 gives the yield of chakka and TS total solids values respectively as mean $\pm \mathrm{SE}$ of six trials obtained from 2 per cent fat enzymatically modified soy substituted synbiotic milk at three different levels that is $10 \%, 15 \%$ and $20 \%$ cultured with Bifidobacterium longum. The percentage of yield of chakka from control, $\mathrm{SSyM}_{10}, \mathrm{SSyM}_{15}, \mathrm{SSyM}_{20}$ were 22.32, 23.01, 24.63 and 25.11 respectively. The percentage of total solids in control, $\mathrm{SSyM}_{10}, \mathrm{SSyM}_{15}$ and $\mathrm{SSyM}_{20}$ were $61.57,59.56,57.88$ and 54.38 respectively.

\section{Discussion}

In the experiments conducted it was found that the yield of chakka from $\mathrm{SyM}_{15}$ is $24.63 \pm 0.99$ and there is significant increase in yield of chakka with addition of neutrase in soy enriched enzymatically modified probiotic shrikhand.The amount of coagulable proteins present in milk and soy milk likely be raised due to addition of neutrase. Neutrase is a bacterial protease produced by a selected strain of Bacillus amyloliquefaciens. Neutrase will break down proteins to peptides. The addition of neutrase results in proteolytic breakdown of milk proteins and soy proteins which results in higher proportion of peptides in shrikhand and hence resulted in higher yield of chakka. (Pokora, 2013) ${ }^{[5]}$.

Total solids recovery obtained from $\mathrm{SSyM}_{15}$ sample is 57.88 \pm 0.42 . There was significant decrease in total solids recovery with increasing substitution of Neutrase at $\mathrm{SSyM}_{10}, \mathrm{SSyM}_{15}$ and $\mathrm{SSyM}_{20}$. (Patel et al, 1985) ${ }^{[4]}$.
Very high hydrolytic and mild lipolytic activity of enzyme neutrase may result in loss of proteins and lipids bringing in lower total solids recovery in enzymatically modified soy milk substituted probiotic shrikhand. (Singh et al, 2014) ${ }^{[6]}$. The enzyme supplementation had accelerated the activity of proteolysis and lipolysis. (Keqinl et al, 2010) ${ }^{[7]}$.

\section{References}

1. Boghra VR, Mathur O. Physico-chemical status of major milk constituents and minerals at various stages of shrikhand preparation. J Food sci. Technol. 2000; 37(2):111-115

2. Food Safety, Standards Authority of India, Ministry of Health and Family WelfareGovernment Of India New Delhi- FSSAI Manual method of analysis of foods: Milk and milk products. $2015 ; 66: 126$.

3. Kulkarni C, Belsare N, Lele A. Studies on shrikhand rheology. J. Food Eng. 2006; 72(2):169-177.

4. Patel RS, Chakraborty BK. Reduction of curd-forming period in shrikhand manufacturing process. le lait. 1985; 65(1):55-64.

5. Pokora M, Eckert E, Zambrowcz A et al. Biological and functional properties of proteolytic enzyme-modified egg protein by-products. Food Sci Nutr. 2013; 1(2):184-195.

6. Singh KV, Kumar R, Singh L, Bhaskar ML. Effect of SNF levels of milk on the quality of shrikhand. J. of Rural and Agric. Res. 2014; 14(1):47-48.

7. Keqin OU, Yunzhu L, Zhang L, Yang X, Huang Z, Robert MJ et al. Effect of Neutrase, Alcalase, and Papain Hydrolysis of Whey Protein Concentrates on Iron uptake by Caco-2 Cells. J. Agric. Food Chem. 2010; 58:48944900. 